\title{
Erratum to: Recombinant human prolactin promotes human beta cell survival via inhibition of extrinsic and intrinsic apoptosis pathways
}

\author{
L. F. Terra - M. H. Garay-Malpartida • \\ R. A. M. Wailemann • M. C. Sogayar • L. Labriola
}

Published online: 15 April 2011

(C) Springer-Verlag 2011

\section{Erratum to: Diabetologia}

DOI 10.1007/s00125-011-2102-z

Unfortunately, the figure parts were incorrectly cited in the text. The correct citations are given in the table below.

\begin{tabular}{ll}
\hline Citation in paper & Correct citation \\
\hline Fig. $1 \mathrm{a}$ & Fig. $1 \mathrm{a}-\mathrm{f}$ \\
Fig. $1 \mathrm{~b}$ & Fig. $1 \mathrm{~g}-1$ \\
Fig. $2 \mathrm{a}-\mathrm{c}$ & Fig. $2 \mathrm{a}-\mathrm{f}$ \\
Fig. $2 \mathrm{~d}$ & Fig. $2 \mathrm{~g}, \mathrm{~h}$ \\
Fig. $3 \mathrm{a}$ & Fig. $3 \mathrm{a}, \mathrm{b}$ \\
Fig. $3 \mathrm{~b}$ & Fig. $3 \mathrm{c}, \mathrm{d}$ \\
Fig. $4 \mathrm{a}$ & Fig. $4 \mathrm{a}, \mathrm{b}$ \\
Fig. $4 \mathrm{~b}$ & Fig. $4 \mathrm{c}, \mathrm{d}$ \\
\hline
\end{tabular}

The online version of the original article can be found at http://dx.doi. org/10.1007/s00125-011-2102-z.

L. F. Terra $\cdot$ M. H. Garay-Malpartida $\cdot$ R. A. M. Wailemann •

M. C. Sogayar $\cdot$ L. Labriola

NUCEL, University of São Paulo,

São Paulo, Brazil

L. F. Terra $\cdot$ R. A. M. Wailemann • M. C. Sogayar •

L. Labriola $(\bowtie)$

Biochemistry Department, Chemistry Institute,

University of São Paulo,

Av. Prof. Lineu Prestes 748, Bloco 9 sup, Sala 964,

São Paulo 05508-900 SP, Brazil

e-mail: labriola@iq.usp.br

M. H. Garay-Malpartida

EACH, University of São Paulo,

São Paulo, Brazil
In addition, a symbol indicating a statistically significant difference of $p<0.05$ for caspase activity in the presence of rhPRL vs control conditions was omitted from parts $d$ and $f$ of Fig. 2. The corrected graphs are shown below.
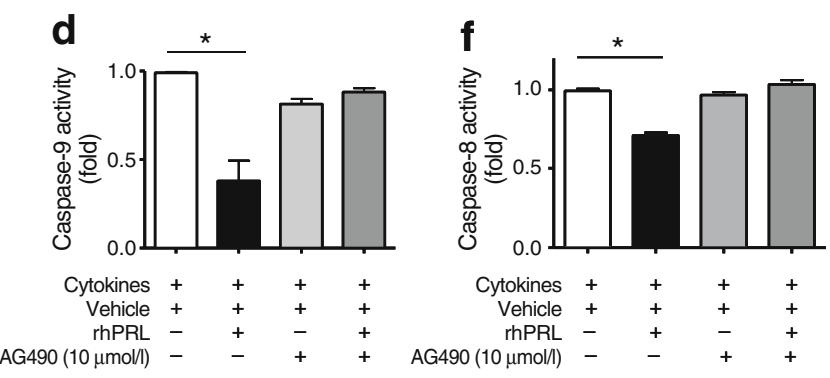

Fig. 2 rhPRL inhibits caspase activity, but does not interfere with nitric oxide production upon serum starvation and cytokine-induced apoptosis. Cells were subjected to serum starvation $(\mathbf{a}, \mathbf{c}, \mathbf{e}, \mathbf{g})$ or treated with a combination of cytokines $(\mathbf{b}, \mathbf{d}, \mathbf{f}, \mathbf{h})$ in the presence or absence of rhPRL $(200 \mathrm{ng} / \mathrm{ml})$. After $48 \mathrm{~h}$ treatment, cells were collected and lysed in an apropriate buffer. (a, b) Caspase-3, (c, d) caspase- 9 and $(\mathbf{e}, \mathbf{f})$ caspase- 8 activities were measured by a fluorimetric assay using a specific substrate and data normalised relative to total protein content. $(\mathbf{g}, \mathbf{h})$ Nitric oxide $(\mathrm{NO})$ production was measured on the supernatant fraction of cells maintained in the above conditions using a fluorimetric assay, with data normalised relative to total protein content. Results are mean $\pm S E M ; n \geq 3$ independent experiments; ${ }^{*} p<0.05$ for difference compared with control situation, which was set at 1 